"The EUrASEANs: journal on global socio-economic dynamics"

Volume 1 (26); January-February, Year 2021;

ISSN $2539-5645$ (Print)

Copyright (C) 2021, [The EUrASEANs]

on-line access: https://www.euraseans.com/1(26)

All issues of this journal are alternatively stored and archived by: the National Library of Thailand, Russian E-library and Index Copernicus

library of journals, Poland

\title{
HNWIS INVESTMENTS: \\ TRENDS AND THE CAPACITY TO ATTRACT (VISEGRAD REGION CASE STUDY)
}

\author{
Ani Galstyan \\ Russian-Armenian University, Yerevan, Armenia
}

Availability of "high net worth individuals" (HNWIs) in a country indicates the level of its wealth. The Visegrad countries represent a substantial part of the EU - one tenth of the community's economy. The current paper focuses on the exploration of the current trends in HNWIs market development, their role in the country's development, identifying the economic capacity of the Visegrad countries to attract HNWI funds. The currently relevant problem for this region is the continuation of its growth while mitigating high foreign capital dependency. The research results show that the Visegrad Group needs initiatives that stimulate its startup deal flow in more advanced startup scenes, attracting local private capital and more business skills. The paper contributes to literature on HNWI investments by identifying vulnerable features of economic development of the Visegrad countries which is responsible for the low HNWI attraction in relation to the current economic issues of the region.

Keywords: HNWI; venture capital; Visegrad group; foreign capital; private investments

\section{Introduction}

The presence of "high net worth individuals" (HNWIs) in a country usually indicates the level of its wealth as well as GDP but from another perspective. This wealth includes private wealth held by all HNWIs living in a country, in particular, all their assets in the form of property, equities, cash and business interests. The assessment of a country's financial wellbeing from the perspective of the HNWIs contribution is important as the wealth held by HNWIs takes into account some vital aspects that the GDP does not take into account. According to the Global Wealth Migration Review (New World Wealth, 2018), the arguments in favor of using private wealth indicators as a measure of financial well-being of countries instead of already traditional GDP indicator are the following.

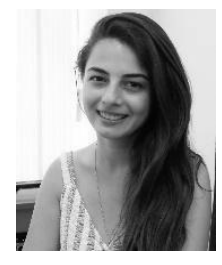

\section{Ani Galstyan}

Lecturer at the Department of Economics and Finance, Russian-Armenian (Slavonic) University, Yerevan, Armenia

Research interests: migration, exchange rate regulation, economic growth.

E-mail: ani.galstyan@rau.am 


\section{HNWIS INVESTMENTS:}

In some countries, like Kuwait, a considerable portion of GDP goes to the government and consequently has a small impact on private wellbeing creation. Furthermore, assessment of financial health of the countries in terms of GDP ignores the sufficiency of the local stock market and banking sector at maintaining wellbeing in a country (New World Wealth, 2018). It also should be added that the citizenship of HNWIs in a particular country is an important measure of its financial wellbeing as HNWIs are the first to leave for another country, if their current country of citizenship faces serious issues. These possible issues are related to an increase in the crime level, lack of business opportunities, religious pressure and so on.

The current paper focuses on the exploration of the current trends in HNWI market development, their role in countries' development, identifying in particular the economic capacity of the Visegrad countries to attract HNWI funds. The Visegrad countries represent a substantial part of the EU - one tenth of the community's economy as a whole. If considered in unity, the Visegrad Group is the fifth largest economy in Europe. The centuries-long shared history, the latest shared experience of the socialistic regime, its breakdown, and then later EU accession, have shaped similarities in mentalities and established trust within the overall region. At the same time, a number of strengths and weaknesses are also very much similar. The region has achieved advances in many convergence indicators, not least due to high FDI inflows. However, two distinctive negatives in the development of the region can be outlined: high dependency on foreign capital and a still considerable lagging behind Western Europe countries. Thus, currently, one of the most relevant problems for the region under consideration is to continue its growth along with targeting the mitigation of high foreign capital dependency.

The current paper contributes to literature on HNWI investments role by identifying vulnerable features in the economic development of the Visegrad countries responsible for low HNWIs attraction in relation to current economic issues of the region.

The paper is structured as follows. The second section considers the most recent trends in HNWI market development. The third section analyses the factors attracting HNWIs. The fourth section considers the contribution of HNWIs to the economy emphasizing their role in sustainable development and stimulating environment-related effects along with the impact on real estate market and possible effects from the related charitable activities. The fifth section views the economic position of the Visegrad region. The sixth section considers the capacity to attract venture capital and private equity funding in the Visegrad region. The final part provides key findings and conclusions.

\section{Literature review: recent trends in HNWI market development}

At the core of the migration mechanism for the category of HNW migrants (Danaj et al. 2018; Škuflić \& Vučković, 2018) are the so-called "investor visa programs" which are becoming progressively popular, in particular, with HNWIs from the Middle East and Asia. They commonly demand an investment of between US\$300,000 and US\$3 mln in local businesses, bonds and property. A greater part of this money is typically offset after a fiveyear period. Some programs such as the one in Malta propose citizenship, rather than a residence visa. Nevertheless, despite the present rise of such programs, it should be noted that only around $20 \%$ of HNWIs migrate under investor visa programs. Many HNWIs still come in via family or spousal visas, work transfers, ancestry visas and second passports (New World Wealth, 2018). 
The latest data shows that 2017 year was the second-fastest year since 2011 in terms of HNWI wealth growth (beaten only by $13.8 \%$ growth rate in 2012-2013). Sound HNWI wealth growth was to a great extent caused by substantial equity market growth due to global market capitalization growth by $21.8 \%$ in 2017 . Soaring business and consumer confidence led to higher investor confidence in the market pushing stock markets upward in 2017 across Asia-Pacific - 25.8\%, Western Europe - 25.8\% and North America - 17.3\%.

The top three global economies in terms of GDP witnessed market capitalization increases of $22.9 \%$ - Japan, $19 \%$ - China and $17.4 \%$ - the USA. Notably, equity-market laggards - China, Switzerland and Italy — changed course in 2017 and maintained sound market effectiveness during the year that stimulated high HNWIs wealth growth. An additional key driver for HNWIs wealth growth was real estate growth in Japan - by $13.2 \%$, Australia - by $7.4 \%$ and in Canada - by $7.1 \%$.

The Asia-Pacific region sustained its growth strength and expanded its lead in HNWI wealth and population over North America with US\$21.6 trln in HNWIs wealth and 6.2 mln HNWIs representing $14.8 \%$ growth (versus $8.2 \%$ back in 2016) and $12.1 \%$ (versus $7.4 \%$ back in 2016) respectively. Asia-Pacific accounts for $30.8 \%$ of the global HNWIs wealth and $34.1 \%$ of the global HNW population.

North America represents the second top region in terms of HNWI wealth and population accumulation. The region accounts for $28.2 \%$ of HNWI wealth and $31.3 \%$ of the global HNWI population.

However, Europe is the third-largest region in terms of HNWIs wealth and population growth. The performance of European region in 2017 recorded 8.2\% HNWIs wealth growth and $7.7 \%$ HNWI population growth. Strong equity market growth in Germany stimulated HNWI market growth of $7.6 \%$ in 2017 due to GDP growth and market capitalization as an outcome of higher consumer spending, exports and employment accompanied by very low lending rates. Ireland's HNWI market showed the highest growth with a $16.3 \%$ increase in wealth and $15.3 \%$ increase in HNWI population. A lower equity rate than in other European countries and real estate in the UK as well as a stagnant economic performance resulted in a $2.1 \%$ growth in HNWI wealth and $1.2 \%$ growth in HNWI population which is lower than Europe's average $-7.8 \%$ and $7.3 \%$ respectively (Capgemini, 2018).

\section{Factors attracting $\mathrm{HNWIs}$}

In 2015, the European Migration Network (EMN) reported on the post-recession phenomenon of the strategy and execution by the Member States of the policies to attract a group of migrants not presently addressed by the EU laws, specifically investors and entrepreneurs. The 2015 EMN study "Admitting third-country nationals for business purposes" investigated a wide range of non-harmonised policies and practices in place to attract these groups in order to support the growth of new enterprises, boost investments and job creation. National policies and programmes were established to suggest a range of incentives such as favourable tax regimes; measures to ease admission; and enhanced rights such as accelerated family reunification, whilst striving to ensure effective controls and safe borders. Currently, at the EU level, there are no legal instruments or schemes to attract these groups (European Migration Network, 2018; Kelly \& Hedman, 2016; Šprocha et al., 2018). Thus, national governments have to rely on their own strategies and tools to attract HNWIs.

It should be noted here that financial being of a country from the viewpoint of private wealth measure, for instance, measured via the capital of individuals in the form of equities, 


\section{HNWIS INVESTMENTS:}

business interests, property, cash, etc. suggests that the development of business environment is a crucial factor for the attraction of HNWI capital. Thus, taxation regime plays a very important role in this context. For instance, Monaco and the Bahamas are widely known all around the world as being offshore centers. There is no income tax in these countries, and this fact alone attracts wealthy individuals. Another important feature of the countries which attract wealthy individuals is strong stock market gains during the year. The highest share in the portfolio of financial asset allocation of HNWIs during 2016-2017 belongs to equities (31.1\% and 30.9\%). Assets held in cash and cash equivalents were at $27.3 \%$ and $27.2 \%$ respectively, real estate investments - at $14 \%$ and $16.8 \%$, fixed income $-18 \%$ and $15.8 \%$, alternative investments (including hedge funds, structured products, foreign currency, derivatives private equity and commodities) - at $9.7 \%$ and $9.4 \%$ respectively (Capgemini, 2018).

Stock market indices in such countries as Poland and Hungary both grew over $40 \%$ during 2016-2017 and the growth rates of New Zealand, USA, Luxembourg, Switzerland, Malta, Mauritius, Israel and Australia were accompanied by the continuing migration of wealthy individuals to these countries (New World Wealth, 2018).

Among other factors, which attract HNWIs, is a beneficial geographical location, with beautiful sea scenery and/or mountains. Monaco, again, is a great example in this regard as it is located on a prime part of the French Riviera. English-speaking countries are characterized by higher financial health and wealth. Other, more specific reasons for choosing a destination country by HNWIs can be also mentioned here. For example, the location of Australia makes it a better base for doing business in Asian countries such as South Korea, Singapore, China, Japan, Hong Kong and Vietnam. Another specific factor is the ongoing Brexit, due to which some of HNWIs have already left the country, primarily due to relatively favorable taxation levels in other European countries. For example, inheritance taxes are substantially high in the UK and France, and much lower in other countries of the same region.

The abovementioned factors may considerably contribute to an increase in the inflow of HNWIs to some countries, but at the same time, there are reasons which may prevent the economic development of countries resulting in a negative wealth growth. Notable examples in this regard are Qatar and Iran, as both had a five percent negative wealth growth during 2016-2017 due to weakening ties with the neighbouring countries - Egypt, Saudi Arabia and the UAE, and also due to strict government control over the most vital economic sectors. During the same period such countries as Pakistan and Nigeria had a ten percent negative growth due to safety concerns.

The strengths of a country's currency may also have a significant impact on the country's ability to attract HNWIs. A striking example was a considerable depreciation of GBP against USD from approximately US\$2.0/£ at the end of 2007 to US\$1.35/£ at the end of 2017. This factor alone has caused a decline in the UK's wellbeing, if measured in USD, during a ten-year period between 2007 and 2017 (Bolečeková et al., 2018; New World Wealth, 2018).

Table 1 represents the top ten countries in terms of HNWIs and top ten countries as to multi-millionaires. In addition to the mentioned countries in Table 1, such countries as Luxembourg, Mauritius, Cyprus, Spain, Monaco, Portugal and Malta experienced considerable inflows of HNWIs in 2017 (New World Wealth, 2018). 
Table 1 - Top 10 countries for multi-millionaires and top 10 countries for HNWIs, 2017

\begin{tabular}{|c|c|c|c|c|c|}
\hline \multicolumn{3}{|c|}{ Multi-millionaires } & \multicolumn{3}{c|}{ HNWIs } \\
\hline Rank & Country & Measure & Rank & Country & Inflow \\
& & & & & \\
\hline 1 & USA & 221580 & 1 & USA & 5047400 \\
\hline 2 & China & 40930 & 2 & Japan & 1340900 \\
\hline 3 & UK & 26130 & 3 & China & 877700 \\
\hline 4 & Japan & 25470 & 4 & UK & 826900 \\
\hline 5 & Germany & 25070 & 5 & Germany & 813300 \\
\hline 6 & Switzerland & 21400 & 6 & Switzerland & 406900 \\
\hline 7 & India & 20730 & 7 & Australia & 376600 \\
\hline 8 & Canada & 12510 & 8 & Canada & 372700 \\
\hline 9 & Australia & 12340 & 9 & India & 330400 \\
\hline 10 & Hong Kong & 11200 & 10 & France & 305200 \\
\hline
\end{tabular}

\section{The contribution of the HNWIs to the economy}

\section{Sustainable development and environment related effects}

According to the European Association for the Promotion and Advancement of Sustainable and Responsible Investment across Europe (the Eurosif) data, HNWIs make significant investments to projects related to sustainable development. In particular, the Eurosif has estimated that in 2007 sustainable investments represented approximately $8 \%$ of all European HNWIs' portfolios. The total European HNWI financial wealth was estimated at $€ 6.7$ trillion, $€ 540$ billion of which transformed into an EU HNWI sustainable investment market. Furthermore, the Eurosif highlighted that the HNWI sustainable investment segment corresponded to around 20-30\% of the European institutional SRI (Socially Responsible Investment) market in 2007 (Eurosif, 2008). Thematic investments were focused mainly on the environmental issues such as energy and climate. Whereas health or life quality funds exist, they are less frequently preferred by HNWIs, possibly indicating that the chosen strategy to influence social change by HNWIs still impacts investments. In particular, the Eurosif data shows that during 2007-2011 HNWIs tended to invest in clean energy - 21\%, in water $-21 \%$, in green technology $-17 \%$, in various multithematic projects $-14 \%$, climate change $-13 \%$, health/ life quality $-12 \%$, and in other projects $-3 \%$ (Eurosif, 2012).

What is also here is that HNWI capital may play a great role at every stage of the conservation investment life cycle. Investments in nature conservation projects contain four major phases, in particular, early-stage development, establishment of a business model, replication and commercialization and in all stages following the early-stage development HNWI investments may considerably contribute to conservation project financing.

HNWI investments are distinguished as a highly important source for the implementation of the environment-related projects. One of the examples is global sustainable land use and ecosystem service projects in developing countries in Africa, Latin America and Southeast Asia developed under the European environmental impact investment 


\section{HNWIS INVESTMENTS:}

Althelia Climate Fund, created back in 2011. Together with Credit Suisse, this Fund has created the Nature Conservation Notes, targeted at HNWIs and public institutions willing to invest in conservation projects while receiving target market-rate returns. The projects of the Althelia Climate Fund are aimed at generating conservation impact as well as provision of the environmental assets, such as certified commodities and carbon credits, which can be then sold at premium prices, therefore producing financial returns for investors.

\section{Impact of HNWIs on real estate market}

The HNWI investment may also affect the real estate market. In particular, this can be shown on the example of the USA housing markets. Local housing markets in the USA have fluctuated in high synchronicity with foreign stock markets during the last few years which was also accompanied by the increased HNWI cross-border investment associated with a number of risks. In particular, markets may become more vulnerable if cross-border investments become too highly levered or if they are focused on locations, where inhabitants do not have enough resources to adapt to the resulting fluctuations. Municipal governments, however, still have a responsibility to ensure that investors pay their fair share for the use of public services, and states and agencies have to keep financing arrangements and securities offerings to ensure that investors are not abusing tax incentives or other subsidies (DeskarŠkrbić et al. 2018; Kakaš, A. 2017). Economic policymakers should prevent asset bubbles, which cross-border investments have caused in other countries in the past. If these provisions are met, HNWIs may actually play a positive role in real estate markets (Orlando, 2018).

\section{Charitable activity of HNWIs}

According to the U.S. Trust Study of High Net Worth Philanthropy (2016) 91\% of HNW households gave to charity in 2015, and almost a half $(49.7 \%)$ of HNWIs volunteered their time. On average, HNW households gave US\$25,509 to charity in 2015. In contrast, households in the general population gave US\$2,124 in 2015. The report highlighted that, although not as many HNWIs volunteer - $49.7 \%$ as opposed to giving to charitable organizations $-91.0 \%$, volunteering has influenced charitable giving. The majority of $\mathrm{HNW}$ volunteers $-84.3 \%$ gave to at least some of the organizations with which they volunteer, and majority of these volunteers $(69.2 \%)$ gave to most or even all of the non-profit organizations for which they were volunteering. Furthermore, nearly a quarter (24.4\%) of HNW households gave to political campaigns, candidates and committees. More than half of HNW donors $(56.3 \%)$ made their contributions in order to exercise their voices and almost half (49.3\%) stated that they contribute to political campaigns in order to have an impact on electoral outcomes.

According to the same report, the following percentage of HNW donors supported the charitable activity in the following categories: basic necessities $-63 \%$, religious $-49.6 \%$, health $-40.2 \%$, in combination (including United Way, United Jewish Appeal, Catholic Charities, and community foundations) - 38.2\%, youth/family services $-36.1 \%$, K12 education $-33.4 \%$, animals $-32.5 \%$, higher education $-31.3 \%$, arts and culture $-26.85 \%$, environment $-21 \%$, international activities $-11.2 \%$, other $-23.5 \%$.

Thus, charitable activity of HNWIs may have a positive impact on those sectors of the development, which are often lacking funds. In particular, local governments are often faced with lack of funding for different needs that can be supported by charitable funds targeted at HNWIs. 


\section{Economic position of the Visegrad region}

The Visegrad group represents around one tenth of the EU economy. The average living standard per capita in the region is above $70 \%$ of the EU's standard. If considered as a single state, the Visegrad Group represents the fifth largest economy in Europe: Hungary, Slovakia, Czech Republic and Poland together have $64 \mathrm{mln}$ people of overall population. This is equal to one fifth of the US population. The centuries-long shared history, the latest shared experience of the socialistic regime, its breakdown, and further EU accession, have shaped very much similar mentalities in the region and established trust within the overall region. There is also a number of commonly shared strengths and weaknesses.

Czech Republic, Poland and Slovakia have reached a considerable convergence in GDP per capita with the EU over the last ten years (Tilford, 2018). However, after the 2008 global economic crisis and its consequences, the approach of relying on the FDI as the main factor of growth has been progressively questioned (Crespo Cuaresma et al., 2014). While the positive developing effects of FDI have been questioned for some time, the 2008 crisis have shown just how vulnerable can be open small market economies, like Slovakia or Hungary, especially in the context of a much larger worldwide business cycle (Galgóczi \& Drahokoupil, 2017). Industrialization strategies based only on great FDI inflows have resulted in dependent development in the region. The Visegrad region is still characterized by a high dependency on foreign investments. Polish economy is the largest economy in this group, it is also the most diversified among them, however, it is still significantly dependent on FDI. Despite the fact that labor productivity and living standards have become considerably higher in this region, labor costs in the Visegrad countries remain lower than in Western Europe (Wang, 2019).

Another problem is the lack of sufficient education in the Visegrad countries. Although vocational training systems and apprenticeship in all four countries are quite strong, the levels of higher education and advanced technical training are less so, primarily because many highly-skilled workers have already migrated to more prosperous EU member states.

It should be also mentioned that Visegrad governments, just like some others in the EU member states, have cut their investments in education and training during the latest several years in order to manage the public budget deficit (Galgóczi \& Drahokoupil, 2017).

Thus, the current situation raises the question whether foreign investors will keep investing in the Visegrad region or will be looking for more educated and skilled labor force with lower costs at the same time. This additionally emphasizes the importance of the local HNWIs attraction.

Capacity to attract venture capital and private equity funding into the Visegrad region

The startups' funding in the Visegrad region in some cases heavily rely on government financing. Venture capital activity is still quite low, and we can hardly anticipate a bubble in the segment any time soon. Local HNWIs only recently have come to the idea of investing in startups, and to date not much support from private sources is available for startups in the region in question.

In Tab. 2 we have presented data on the venture capital and private equity market in the Visegrad countries. In this table one can see that Hungary and Poland are characterized by considerably more intensive venture capital and private equity market activity. It should be noted that additionally to low VC industry activity, there is also a problem with national legal restrictions. In Czech Republic the VC industry is commonly funded by the capital of foreign 


\section{HNWIS INVESTMENTS:}

HNWIs through their investment companies (European Investment Fund, 2007). Financing sources for VC funds come from insurance companies, pension funds, banks and government agencies. However, in Czech Republic, the law considerably restricts the participation of insurance companies and pension funds in such types of investing. Local funds oriented towards VC are too small and therefore uninteresting for foreign investors. Thus, local sources for these funds are lacking. This is a problem for other CEE countries too, as only $4 \%$ of the total fundraising comes from local private investors.

Table 2 - Venture capital and private equity market in the Visegrad countries

(Source: Polish Development Fund, 2015)

\begin{tabular}{|l|c|c|c|c|}
\hline Value in EUR & $\begin{array}{c}\text { Czech } \\
\text { Republic }\end{array}$ & Hungary & Poland & Slovakia \\
\hline \multicolumn{5}{|c|}{ Stages of development } \\
\hline Seed & 0 & 1,496 & 1,820 & 800 \\
\hline Startup & 2,933 & 22,174 & 9,722 & 900 \\
\hline Subsequent rounds & 6,134 & 8,477 & 10,472 & 3,000 \\
\hline Total investment & 9,067 & 32,146 & 22,014 & 4,700 \\
\hline
\end{tabular}

The Visegrad countries performance in terms of the capacity to attract $\mathrm{VC}$ and private equity funding is relatively low. According to the VCPE Country Attractiveness Index 2018 (see Tab. 3 further), Slovakia was ranked the worst among all Visegrad countries while Poland was ranked the highest.

From all of the above, it can be seen that Slovakia, Czech Republic and Hungary are considerably lagging behind in terms of the Depth of Capital Market indicator. Czech Republic is ranked 98 out of 125 countries included in the analysis in terms of Size and Liquidity of the Stock Market, however, a much better rank belongs to Poland. In terms of taxation, Poland is ranked the best, however, all four Visegrad countries do not actually provide many tax reliefs for investors. There are no tax exemptions or deductions for corporate business. Corporate income tax is the highest in Slovakia - 21\%, the lowest is in Hungary - 9\%, tax rate in Czech Republic and Poland is 19\% (World Bank, 2019). In terms of Investor Protection and Corporate Governance indicator, however, the highest ranking was held by Czech Republic and all its sub-indicators as well. Performance of Czech Republic on Human and Social Environment and Entrepreneurial Opportunities was also the highest among the entire Visegrad group.

\section{Conclusions}

The current paper aimed to explore the current trends in the HNWI market development, their role in countries' development, identifying, inter alia, the economic capacity of the Visegrad countries to attract HNWI funds.

Our research has shown that strong HNWI wealth growth was to a great extent caused by substantial equity markets growth due to global market capitalization growth. An additional key driver for HNWI wealth growth was real estate growth. From the global 
perspective, three world regions are the leaders in attracting HNWIs: Asia-Pacific, North America and Europe, in particular, Western European countries, or the so-called Old Europe.

Table 3 - VCPE Country Attractiveness Indices for the Visegrad countries (Sources: Groh et al., 2018)

\begin{tabular}{|l|c|c|c|c|}
\hline & Slovakia & $\begin{array}{c}\text { Czech } \\
\text { Republic }\end{array}$ & Hungary & Poland \\
\hline VCPE Country Attractiveness Index & 71 & 33 & 52 & 26 \\
\hline Economic Activity & 65 & 28 & 43 & 19 \\
\hline Depth of Capital Market: & 78 & 61 & 64 & 22 \\
\hline $\begin{array}{l}\text { Size and Liquidity of the Stock } \\
\text { Market }\end{array}$ & 71 & 98 & 73 & 15 \\
\hline Total Trading Volume & 74 & 46 & 48 & 35 \\
\hline IPOs and Public Issuing Activity & 91 & 47 & 73 & 19 \\
\hline M\&A Market & 67 & 42 & 58 & 19 \\
\hline Debt and Credit Market & 38 & 24 & 78 & 21 \\
\hline Bank Non-Performing Loans & 64 & 67 & 94 & 60 \\
\hline Financial Market Sophistication & 38 & 37 & 59 & 42 \\
\hline Taxation & 43 & 48 & 49 & 24 \\
\hline $\begin{array}{l}\text { Investor Protection and Corporate } \\
\text { Governance: }\end{array}$ & 71 & 36 & 74 & 57 \\
\hline Quality of Corporate Governance & 66 & 50 & 71 & 54 \\
\hline Security of Property Rights & 74 & 43 & 65 & 72 \\
\hline Quality of Legal Enforcement & 73 & 39 & 74 & 49 \\
\hline Human and Social Environment & 69 & 18 & 48 & 34 \\
\hline Entrepreneurial Opportunities & 46 & 26 & 45 & 34 \\
\hline
\end{tabular}

It has been found out that currently, at the EU level, there are no legal instruments or schemes to attract investors and entrepreneurs. Thus, national governments are forced to rely on their own strategies and tools to attract HNWIs.

The most important economic features of the countries, which attract HNWIs, are as follows: currency strengths, overall business environment climate, taxation regime and stock market development. The following effects of HNWIs on the economy have been outlined: promotion of sustainable development and stimulating environment related effects; positive impact on real estate market and possible positive effects of charitable activity. 


\section{HNWIS INVESTMENTS:}

Our analysis has determined that there are much strength in economic development of the Visegrad group. However, industrialization strategies based only on great FDI inflows have resulted in dependent development in the region overall.

It has been indicated that local HNWIs in the region only recently have initiated investing in startups, and not much support is now available to startups from private sources. The Visegrad countries performance in terms of capacity to attract VC and private equity funding is relatively low. According to VCPE Country Attractiveness Index 2018, Slovakia is ranked the worst among all Visegrad countries and Poland is ranked the highest.

Slovakia, Czech Republic and Hungary considerably lagged behind in terms of the Depth of Capital Market indicator. Czech Republic was ranked 98 out of 125 countries included in the analysis in terms of Size and Liquidity of the Stock Market, however, a much better rank was held by Poland. In terms of taxation Poland ranked the best, however, generally speaking, all four Visegrad countries do not really provide many tax reliefs for investors. There are no tax exemptions or deductions for corporate business either.

Due its small market size and VC activity scale, the region under consideration still lacks key competences and sound players who could attract key institutional investors and could also support portfolio companies and develop them globally.

More importantly, we can conclude that the Visegrad countries need to turn their development strategies away from the present preponderant dependence on FDI, which is essential, of course, but will not lead to persistent convergence in living standards, particularly in an economy the size of Poland's. Instead of competing to suggest the most favourable tax regime for foreign investors, the economies in question need to focus on guaranteeing that local companies would have what they need to prosper - sufficient volume of skilled labor, finance, infrastructure, transparent and foreseeable business environment.

The Visegrad Group, thus, needs initiatives that would stimulate its startup deal flow in more advanced startup scenes, attracting local private capital and higher excellence in business skills. As discussed before, an already high dependency level on foreign capital signalizes great uncertainty for future development of the region. Thus, the focus should be shifted on attracting local HNW investments. In order to attract such funds, the following directions of macroeconomic policies will contribute to HNWIs attraction: market competition stimulation, improvement of labor market dynamics, absorptive capacity of domestic firms, R\&D organizations and universities, development of employee skills, education and a better business environment.

\section{References:}

Bolečeková, M., Olejárová, B. \& Ostasz, G. (2018). Instruments of migration policy: A case of the Slovak Republic. Journal of International Studies, 11, 225-239.

Capgemini, (2018). World Wealth Report. Retrieved from: https://www.capgemini.com/ch-de/wpcontent/uploads/sites/26/2018/06/Capgemini-World-Wealth-Report-19.pdf.

Crespo Cuaresma, J., Lábaj, M. \& Pružinský, P. (2014). Prospective ageing and economic growth in Europe. The Journal of the Economics of Ageing, 3(C), 50-57.

Danaj, A., Lazányi, K. \& Bilan, Y. (2018). Perceptions and Implications of Immigration in France Economic, Social, Political and Cultural Perspectives. Economics \& Sociology, 11(3), 226247. 
Deskar-Škrbić, M., Drezgić, S. \& Šimović, H. (2018). Tax policy and labour market in Croatia: effects of tax wedge on employment. Economic Research-Ekonomska Istraživanja, 31(1), $1218-1227$.

European Migration Network. (2018). Understanding Migration in the European Union: Insights from the European Migration Network 2008-2018. Retrieved from: http://extranjeros.mitramiss.gob.es/es/redeuropeamigracion/Archivos/ 10_aniversario/

Eurosif (2008). High Net Worth Individuals \& Sustainable Investment. Retrieved from: https://www.financite.be/sites/default/files/references/files/140.pdf.

Eurosif (2012). High Net Worth Individuals and Sustainable Investment 2012. Retrieved from: https://www.eurosif.org/wp-content/uploads/2014/05/1.-report_hnwi.pdf.

Galgóczi, B. \& Drahokoupil, J. (2017). Condemned to be left behind? Can Central and Eastern Europe emerge from its low-wage model? Available online at: https://www.etui.org/publications/books/condemned-to-be-left-behind-can-central-and-easterneurope-emerge-from-its-low-wage-model.

Groh, A., Liechtenstein, H., Lieser, K. \& Biesinger, M. (2018). The Venture Capital \& Private Equity Country Attractiveness Index. Retrieved from: https://blog.iese.edu/vcpeindex/profiles/.

Kakaš, A. (2017). Vzdialenost' ako faktor výskumu vnútornej migrácie Slovenska. Geografický časopis, 69(1), 41-60.

Kelly, M. \& Hedman, L. (2016). Between Opportunity and Constraint: Understanding the Onward Migration of Highly Educated Iranian Refugees from Sweden. Journal of International Migration and Integration, 17(3), 649-667.

New World Wealth. (2018). Global Wealth Migration Review 2018. Retrieved from: https://samnytt.se/wp-content/uploads/2018/02/GWMR-2018.pdf.

Orlando, A. W. (2018). Global forces, local consequences: The role of foreign investment and HNWI money in US real estate markets. Retrieved from: https://doc-research.org/wpcontent/uploads/2018/10/Global-forces-local-consequences_-The-role-of-foreign-investmentand-HNWI-money-in-US-real-estate-markets_Download-file.pdf.

Škuflić, L. \& Vučković, V. (2018). The effect of emigration on unemployment rates: the case of EU emigrant countries. Economic Research-Ekonomska Istraživanja, 31(1), 1826-1836.

Šprocha, B., Šídlo, L., Klapková, M. \& Ďurček, P. (2018). Nové prístupy k hodnoteniu procesu populačného starnutia a ich aplikácia v prípade Slovenska a Európy. Geographical Journal, $70(4)$.

Tilford, S. (2018). All is not well in the Visegrad economies. Centre for European Reform Bulletin, (5). Retrieved from: https://euagenda.eu/publications/all-is-not-well-in-the-visegradeconomies.

Wang, D. (2019). International labour movement, public intermediate input and wage inequality: a dynamic approach. Economic Research-Ekonomska Istraživanja, 32(1), 1-16.

Paper submitted

Paper accepted for publishing

Paper published online
12 September 2020

04 November 2020

31 January 2021 